\title{
The Urgency of Regulating Tax Law for Vehicles After Natural Disasters in Indonesia
}

\author{
Asriyani $^{1}$ \\ Adiesty S. P. Syamsuddin ${ }^{2}$ \\ Soleman S. Rory ${ }^{3}$
}

${ }^{1}$ Lecturer of Law Faculty, Tadulako University, E-mail: anchinatsir88@gmail.com

2Lecturer of Law Faculty, Tadulako University, E-mail: adiestysyam@untad.ac.id

${ }^{3}$ Lecturer of Law Faculty, Tadulako University, E-mail: soleman.rory@yahoo.com

\section{Article Info}

Keywords:

Tax Law; Tax Collection;

Natural Disaster

How to cite (APA Citation Style):

Asriyani, Syamsuddin, A. S. P., Rory, S. S., (2021). " The Urgency of Regulating Tax Law for Vehicles After Natural Disasters in Indonesia" JALREV 3 (2): 253-276

\begin{abstract}
The occurrence of a natural disaster on 28 September 2018 in the province of Central Sulawesi Indonesia caused vehicle tax arrears to be incurred by people who were victims of natural disasters. This research is socio-legal research with a statutory and comparative approach to find out the legal arrangements related to tax collection after natural disasters and to compare it with the practices in New South Wales, Australia. This study concluded that there is no specific regulation that differentiates the mechanism of tax collection during normal times and the period after a natural disaster in Indonesia. Local governments are given the authority to regulate it based on the scale of the disaster and the affected areas/people in which people lose their homes and livelihoods so they cannot fulfill their obligations to pay for vehicle tax. This resulted in the arrears of tax collection carried out by the fiscus and become an obstacle for local governments to collect taxes as a source of financing rebuilding infrastructure after a natural disaster. As a comparison, an integrated tax reduction system was applied for disaster victims in New South Wales, including for the vehicle tax. The whole process was done online. Indonesia needs to build such a system to anticipate the bad impact of tax collection that can make disaster victims suffer psychologically.
\end{abstract}




\section{Introduction}

Taxes are a source of state revenue that determines the success of national development. In a rule of law, tax collection must rely on the principle of constitutional supremacy and the legality of statutory regulations. This is in line with the ideals of a rule of law and constitution that has been adhered to by Indonesia since proclaiming its independence on 17 August 1945 and pledging itself to be an independent nation. A clear example of the results of amendments to the constitution which is very important for efforts to provide national development funds is in the case of taxes where Article 23A stipulates that "Taxes and other levies which are forcing for state purposes are regulated by law". This article emphasizes the existence of taxes for the sustainability of the life of the state for the realization of the goals of the Republic of Indonesia as contained in the fourth paragraph of the opening of the 1945 Constitution, namely "advancing the general welfare".

The main source of revenue and the largest in the State of Indonesia today is tax. Taxes are used to finance the expenditures needed by the government to increase national development and the welfare of the citizens. It is the main source of state revenue which accounts for around $70 \%$ of all state revenues ${ }^{1}$. Taxes have a fairly large contribution to non-oil and gas state revenues. From the fiscal perspective, taxes are state revenues that are used to improve people's welfare with the basic principle of collecting funds obtained from and for the community through the referred mechanism in the laws and regulations ${ }^{2}$. In the last 5 years, tax revenue has been the main source of state revenue for realizing the ideal of "general welfare" of the Indonesian people. In the 2020 State Revenue and Expenditure Budget (APBN), the government is targeting revenue from tax revenue to be $1,865.7$ trillion, or $73.44 \%$ of overall state revenue ${ }^{3}$.

\footnotetext{
${ }^{1}$ Hafifah Nasution and Agista Aliffioni. Analisis Efektivitas Penagihan Pajak dengan Surat Paksa dan Penyitaan untuk Meningkatkan Penerimaan Pajak pada Kantor Pelayanan Pajak Pratama Bekasi Utara". Jurnal Wahana Akuntansi Vol. 13 (2) 2018, page 129-142.

2 Rizka Pertiwi, Novianti Devi Farah Azizah, and Bondan Catur Kurniawan. Analisis Efektifitas Pemungutan Pajak Bumi dan Bangunan. Retrieved from https://media.neliti.com/media/publications/193071-ID-analisis-efektivitas-pemungutan-pajakbu.pdf, (accessed on 30 November 2020)

${ }^{3}$ Ministry of Finance Republic of Indonesia, Anggaran Pendapatan dan Belanja Negara Tahun 2020, Retrieved from https://www.kemenkeu.go.id/single-page/apbn-2020/, (accessed on 11 March 2020)
} 


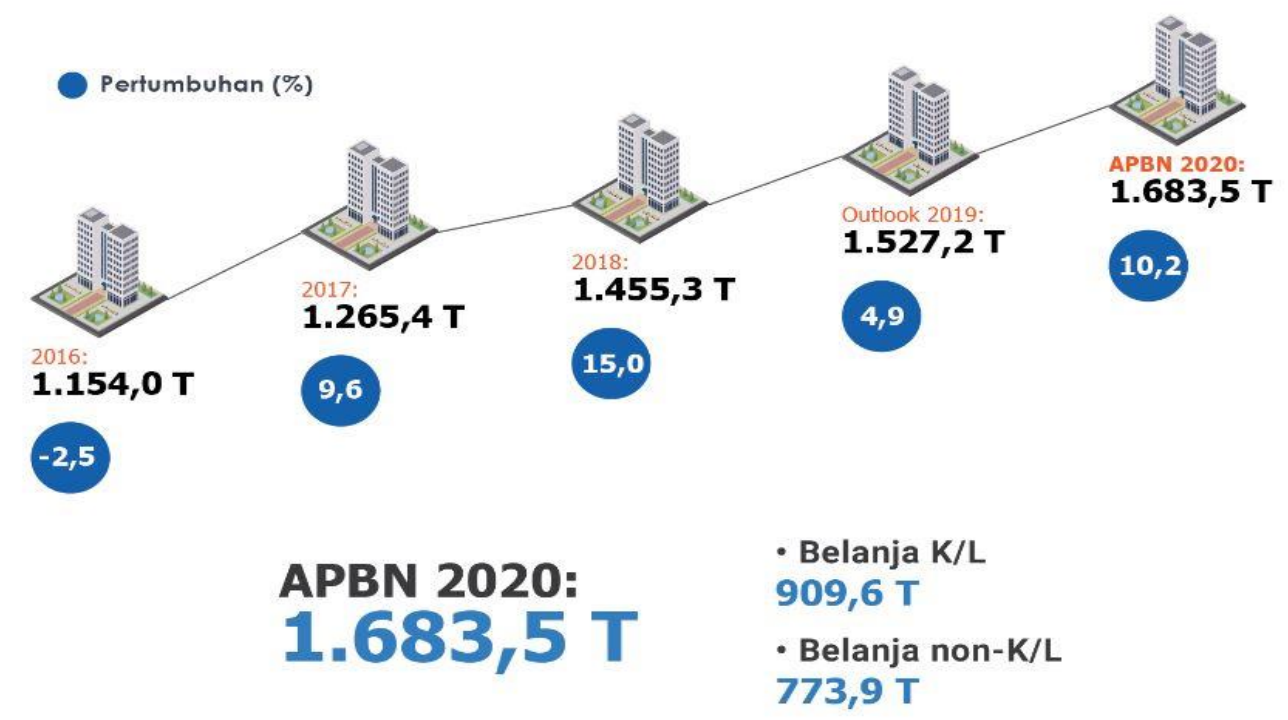

Sources: Ministry of Finance, Republic of Indonesia, 2020.

Figure 1 shows the number of APBN has reached IDR 1.683.5 Trillion in 2020, which increased rapidly compared to the 2016 APBN figure. As previously explained, tax is a contributor to the state budget in the state financial system. Therefore, taxes are one of the elements of development financing covered in the APBN. The projected growth in tax value in the last five years is shown in the following figure 4 :

Figure 2. The growth of taxation of the Republic of Indonesia in the last five years

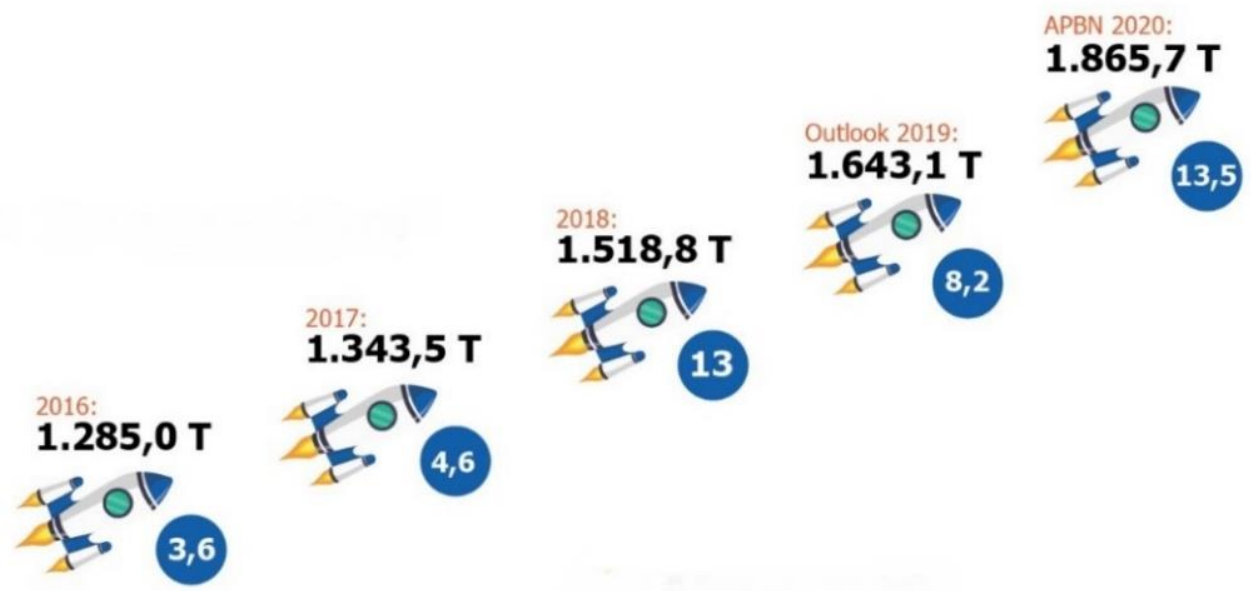

Source: Ministry of Finance, Republic of Indonesia, 2020.

${ }^{4}$ Ibid. 
From this figure, it can be seen that the projected growth of Indonesian taxation has experienced a significant upward trend and the projection for 2020 is the highest tax revenue projection in the last 5 years. This proves that the Government is very serious in making taxes the main source of income for development. Tax is a form of obligation that must be fulfilled by individual and corporate taxpayers ${ }^{5}$. Therefore, every citizen should be aware of his obligation to pay this tax. Institutions that have the authority to collect taxes in Indonesia are the Directorate General of Taxes (DJP) for Central Taxes and the Regional Income and Asset Management Service (DPPKAD) or other similar names for Regional Taxes. Article 23A later became the basis for the formation of Law Number 28 of 2009 concerning Local Taxes and Levies (hereinafter written as the PDRD Act).

In the 2020 State Budget, the State Expenditure post is set at Rp. 2,540.4 trillion, consisting of the Central Government Expenditure Budget, Budget, Transfers to Regions, and Village Funds. The Central Government Budget is subsequently allocated for expenditure items scattered throughout the Ministries or State Agencies, including for paying interest and principal foreign loans, as well as financing subsidies for fuel oil, electricity, and food, as well as building and maintaining public facilities. Citizens enjoy tax money that they pay through subsidies for certain sectors that affect the livelihoods of many people, for example, fuel subsidies, electricity subsidies, fertilizer subsidies, and poor rice procurement (Raskin), construction of public facilities such as roads, bridges, schools, hospitals/Puskesmas, and other financings to improve welfare for all levels of society.

As a country with good purchasing power, the current number of vehicles in Indonesia has reached $146,858,759$ units in $2018^{6}$. This number consists of $120,101,047$ units of two-wheeled vehicles and $26,757,713$ units of four-wheeled vehicles (passenger cars, buses, and cargo cars). Vehicles are regulated in the PDRD Law in Chapter I Article 1 Number 12 which regulates that "Vehicle Tax is a tax on

\footnotetext{
${ }^{5}$ Rudi Hidayat and Charoline Cheisviyanny. (2013). Pengaruh Kualitas Penetapan Pajak dan Tindakan Penagihan Aktif Terhadap Pencairan Tunggakan Pajak. Jurnal Wahana Riset Akuntansi, Vol. 1 No. 1 April 2013.p. 1-20.

${ }^{6}$ Badan Pusat Statistik Republik Indonesia. Perkembangan Jumlah Kendaraan Bermotor Menurut Jenis, 1949-2018. Retrieved from https://www.bps.go.id/linkTableDinamis/view/id/1133, accessed on 13 March 2019)
} 
ownership and/or control of vehicles". The regulations regarding the substance of vehicle tax are then contained in Article 3 to Article 20 of the Law.

Geographically, Indonesia is an area prone to disasters, both natural disasters and ecological disasters caused by humans. Indonesia's unique location (between two continents and two oceans) brings special conditions that are not shared by other countries in the world. In addition, Indonesia is also part of the Pacific ring of fire, a roughly 25,000-mile chain of volcanoes and seismically active sites that outline the Pacific Ocean 7 , which often experiences natural disasters in the form of earthquakes and volcanic eruptions because it is located on a tectonic plate.

After any disaster occurs, multidimensional crises rise in society and it ultimately has an impact on regional financial capacity, particularly influenced local taxes and levies. As a result of the reduction in critical economic activity after a disaster, there has been a decrease in the ability of the community to pay taxes (ability to pay) ${ }^{8}$, especially after a natural disaster where the community suffered material and immaterial losses. In some cases, the community has even lost its source of livelihood.

Unfortunately, this situation does not negate the community's obligation to pay taxes. Because the state still needs taxes to finance development, especially after a natural disaster, where infrastructure and public facilities suffer damage and repaired with financing, one of which comes from taxes. Thus, tax collection is crucial. Two economic consequences of tax collection, namely:

1. Will increase state revenue;

2. Will reduce the funds (money incomes) available in society.

Tax collection must be followed by its use which can provide greater benefits to the community so that the tax collection does not interfere with the people's purchasing power ${ }^{9}$. In addition, W. J. Langen argued that the Principle of Benefit is one of the origins of tax collection in which taxes collected by the state must be used for

\footnotetext{
7 National Geographic. The Ring of Fire. Retrieved from https://www.nationalgeographic.com/science/earth/ring-of-fire/ (accessed on 28 November 2020)

${ }^{8}$ Adrian Sutedi. (2008). Hukum Pajak dan Retribusi Daerah. Bogor: Ghalia Indonesia. p. 102.

${ }^{9}$ H. Bohari. (2004). Pengantar Hukum Pajak. Jakarta: PT. Rajagrafindo Persada. p. 148.
} 
activities that are beneficial to the public interest ${ }^{10}$. Therefore, post-natural disaster collection and collection of taxes is an interesting discourse to discuss because it confronts the interests of the community as victims of natural disasters and the interests of the state to collect taxes.

\section{Problem Statement}

The vehicle tax should be collected in a situation when it is convenient for the taxpayer to fulfill their obligation following Adam Smith's convenience of payment principle. Also, Jeremy Bentham's utilitarianism explained that an action is right when it produces happiness, and wrong when it produces suffering. In this case, the regulation to collect vehicle tax from natural disaster victims may cause discomfort due to their situation.

\section{Methods}

This study is conducted with socio-legal research method ${ }^{11}$. The material for the analysis of this study is obtained with statutory and comparative approaches. The research location is the city of Palu, targeted research subject is the stakeholders of vehicle tax after 2018 disasters in the worst affected areas: SAMSAT Joint Office Palu City, SAMSAT Joint Office Sigi Regency, and SAMSAT Joint Office Donggala Regency. Materials for analysis including data taken from an in-depth interview with the Head of the aforementioned Offices as primary data, because the three offices experienced difficulty in collecting taxes after the disaster. This study also used secondary data sourced from law and regulation on tax vehicle collection, official documents, books, and academic journals. A comparative approach was carried out by presenting the factual state of vehicle tax after a disaster in New South Wales, Australia, to examine the implementation of tax collection and compare it with the current situation in Indonesia.

\footnotetext{
10 Aristanti Widyaningsih. (2011). Hukum Pajak dan Perpajakan dengan Pendekatan Mind Map. Bandung: Alfabeta. p. 12.

${ }^{11}$ Soekanto and Sri Mamudji. (2006). Penelitian Hukum Normatif. Jakarta: PT. Raja Grafindo Persada. p. 12. Also: Mukti Fajar and Yulianto Achmad. 2010. "Dualisme Penelitian Hukum Empiris dan Normatif". Yogyakarta: Pustaka Pelajar. p. 280.
} 


\section{Analysis and Discussion}

\subsection{Regulations of Tax Law}

Provisions regarding vehicle tax are regulated in Article 2 of PDRD Law stipulates that the types of Provincial taxes consist of Motorized Vehicle Tax, Motorized Vehicle Title Transfer Fee, Motorized Vehicle Fuel Tax, Surface Water Tax, and Cigarette Tax. From this provision, it appears that the authority to collect vehicle tax is in the hands of the provincial government. Vehicle tax collection is carried out by the SAMSAT Joint Office which is an integrated system of cooperation between the National Police, the Provincial Revenue Service, and PT. Jasa Rahardja.

Generally, when a natural disaster occurs, the vehicle that is the object of the tax is damaged and/or lost. This results in difficulties in the tax settlement process by the taxpayers. For instance, after the earthquake, tsunami, and liquefaction in Central Sulawesi Province on 28 September 2018, many vehicles were lost to the tsunami. Apart from that, there were also vehicle units that were damaged, either slightly, moderately, or heavily ${ }^{12}$ due to earthquake and liquefaction. The lost or damaged vehicle is subject to tax according to the definition in the PDRD Law.

Taxpayers as owners of vehicles are required to report the condition of their tax objects to the State as tax collectors. Sometimes the specified period cannot be fulfilled by the taxpayer to pay the tax due. Taxpayers can pay in installments or postpone tax payments by asking the tax officials ${ }^{13}$. In practice, after a natural disaster, the people who are victims do not have the opportunity to report the condition of their tax objects, so that the SAMSAT Joint Office experiences difficulties in collecting vehicle tax. Especially if in a natural disaster, taxpayers also lose their homes and have to be relocated. However, the taxpayers remain enthusiastic about fulfilling their tax obligations as shows at the SAMSAT Joint Office in Palu City on

\footnotetext{
12 Kompas. Bangkai Kendaraan Bermotor Akibat Bencana Gempa di Kota Palu. Retrieved from https://foto.kompas.com/photo/read/2018/09/30/15383242987b6/Bangkai-Kendaraan-BermotorAkibat-Bencana-Gempa-di-Kota-Palu, (accessed 30 November 2020)

13 M. Djafar Saidi. (2008). Perlindungan Hukum Wajib Pajak dalam Penyelesaian Sengketa Pajak. Jakarta: PT. Rajawali Pers. p. 153.
} 
Monday, 7 January 201914.

As an example, the collection of vehicle tax according to tax laws and regulations after a natural disaster in Palu City, Sigi Regency, and Donggala Regency is carried out by Central Sulawesi Governor Regulation Number 25 of 2018 (hereinafter written as Pergub No. 25/2018) which regulates the reduction mechanism tax arrears relief for taxpayers. However, the substance of this Pergub does not specifically regulate the collection and/or collection of taxes after natural disasters but rather regulates reduction of principal tax arrears, waiver, and exemption of administrative sanctions in the form of vehicle tax fines and exemption of second transfer of vehicle title fees. This regulation is used by citizens to help settle their tax obligations to the State.

Unpredictable natural disasters are a matter of local government policy because natural disasters often paralyze the wheels and the regional economy so that local governments need central government intervention for reconstruction purposes. In the context of taxation, natural disasters disrupt the flow of taxation based on the scale of the damage at the local economic level of the affected area. Therefore, the government requires adjustments to tax regulations in a post-disaster event to facilitate the process of fulfilling tax obligations for the community. For example, by providing tax incentives, tax relief procedures for victims, extending the payment period, and even eliminating vehicle tax fines. Methods like this also function to support the psychological state of the community in post-disaster economic and social situations.

In the interest of society, tax regulations allow the Director-General of Taxes to reduce, write off, or cancel them out of the office or at the request of the taxpayer. These include:

a. Reducing or eliminating administrative sanctions in the form of interest, fines, and increases owed under the provisions of taxation legislation if the sanctions are imposed due to the taxpayer's negligence, or not because of his fault;

b. Deductor cancellation an incorrect tax assessment or tax collection letter; or

14 Rony Sandhi. Melihat Antusias Warga Bayar Pajak Kendaraan Bermotor Pasca Bencana. Retrieved from https://radarsulteng.id/14850-2/4 (accessed on 30 November 2020) 
c. Cancel the results of the audit or the tax assessment from the results of the audit carried out without:

1) Submission of notification of examination results; or

2) Audit Result Final Discussion with Taxpayer.

Taxpayers can apply for a reduction or cancellation of a tax assessment letter if:

a. Taxpayers do not submit objections to the tax assessment letter; or

b. The Taxpayer submits an objection but the objection is not considered by the Director-General of Taxes because it does not meet the requirements. Application for reduction or cancellation of an incorrect tax assessment cannot be filed if the Taxpayer withdraws the objection submitted to the DirectorGeneral of Taxes.

In practice in Central Sulawesi after the natural disaster on 28 September 2018, the Joint Office of SAMSAT implemented several ways to maximize tax payments, namely ${ }^{15}$ :

a. Deduction of principal tax arrears;

b. Elimination of principal tax arrears;

c. Vehicle tax fine exemption;

d. Exemption from the principal on vehicle name transfer.

The mechanism used is the reporting of vehicle units or lost vehicle ownership documents. This report then becomes the basis for blocking bills by the SAMSAT Joint Office, meaning that billing is not carried out by the SAMSAT Joint Office based on reports from taxpayers. The methods taken to collect taxes put forward the principle of convenience for taxpayers by the principle of the convenience of payment from Adam Smith. This principle states that taxes should be charged at the right time,

15 Pemerintah Daerah Provinsi Sulawesi Tengah. Peraturan Gubernur Sulawesi Tengah Nomor 25 Tahun 2018 tentang Pengurangan Pokok Tunggakan Pajak, Penghapusan, dan Pembebasan Sanksi Administrasi Berupa Denda Pajak Kendaraan Bermotor dan Pembebasan Pokok Bea Balik Nama Kendaraan Bermotor Kedua dan Seterusnya di Provinsi Sulawesi Tengah. 
namely when the taxpayer gets wages, salaries, or other results ${ }^{16}$.

Accordingly, tax collection should be carried out at a good time and not burdens the taxpayer. The post-disaster situation which does not allow taxpayers to obtain wages, salaries, or other results then becomes an obstacle for them to fulfill their tax obligations. Examples of cases that occurred in Central Sulawesi after the natural disaster on 28 September 2018, where several areas experienced earthquakes, tsunamis, as well as liquefaction. Victims of natural disasters in the affected areas then lose their livelihoods but still have to pay taxes, particularly vehicle taxes. In this situation, the victims prioritize the fulfillment of basic needs such as food, clothing, and housing rather than paying the vehicle tax. Especially if the vehicle is lost or damaged as a result of the natural disaster. So that the inconvenience caused by natural disasters should not be exacerbated by the obligation to pay off vehicle taxes.

Taxpayers play an important role in economic development and growth. However, the situation after the disaster did not allow them to immediately fulfill their tax obligations, resulting in tax arrears. Jeremy Bentham's opinion on utilitarianism states that an action is right if it produces happiness, and wrong if it produces suffering. Happiness is meant not only for the perpetrator but also for others who are affected by their action ${ }^{17}$. Happiness is defined as pleasure and the absence of suffering. Pleasure and freedom from suffering are things that are expected as a result and that humans tend to encourage pleasure and prevent suffering ${ }^{18}$.

In this case, tax collection for victims of natural disasters can bring unhappiness to both taxpayers and their families. So, the government should emphasize this in regulations regarding vehicle taxes because natural disasters cannot be predicted, but the consequences and losses that occur after that must be anticipated by the law and the government. Legal regulations related to vehicle taxes after natural disasters will

\footnotetext{
${ }^{16}$ Angger Sigit Pramukti and Fuady Primaharsya. (2015). Pokok-pokok Hukum Perpajakan. Yogyakarta: Pustaka Yustisia. p. 38.

17 IISAUC. Utilitarianisme Jeremy Bentham. Retrieved from https://www.iisauc.org/2020/07/12/utilitarianisme-jeremy-bentham/, (accessed on 13 September 2021.

18 Joseph Losco and Leonard Williams. (2015). Political Theory: Kajian Klasik dan Kontemporer Edisi Kedua. (Indonesian Translation by Haris Munandar). Jakarta: PT. Rajagrafindo Persada. p. 681.
} 
bring legal certainty to the community and prioritize aspects of justice for victims of natural disasters who must think about survival after natural disasters destroy their lives.

\subsection{Inhibiting Factors for the Post-Natural Disaster Vehicle Tax Collection Process}

\section{a. Loss/damage of proof of ownership and vehicle documents belonging to the Taxpayer and loss/damage of the tax object vehicle}

In the 2018 natural disaster in Palu City, residential areas in Petobo and Balaroa experienced liquefaction where all houses and vehicles were destroyed. Therefore, both the owner and/or the vehicle are no longer recognizable and as a result, the taxes are no longer collectible. Likewise in tsunami-affected areas (for example, subdistrict of Lere and Besusu Timur), where many tax, objects were lost to the tsunami and/or were stolen after the tsunami, the taxes could no longer be collected. However, as part of the SAMSAT Joint Office, the National Police (POLRI) promised to facilitate the management of lost vehicle certificates ${ }^{19}$.

The SAMSAT Joint Office provides procedures for physical inspection of tax objects for vehicles that experience document loss. The physical examination includes checking the vehicle frame number which is carried out by the Police as SAMSAT partner $^{20}$. For tax objects that are no longer known (disappeared in the liquefaction/tsunami or lost or being stolen), the taxpayer can report to the Police for a loss document which states that the tax object has been lost/ whereabouts are no longer known. The letter of loss is then becoming the basis for taxpayers to report their tax obligations to the local SAMSAT Joint Office 21.

\section{b. Choice The loss of people's livelihoods after the disaster}

After the disaster occurred, 50,422 households became refugees and lost their

\footnotetext{
19 Irsyaad Wijaya. Polri: Korban Gempa dan Tsunami Dipermudah Urus Surat Kendaraan Hilang. Retrieved from https://otomania.gridoto.com/read/241190510/polri-korban-gempa-dan-tsunamidipermudah-urus-surat-kendaraan-hilang, (accessed 28 November 2020)

${ }^{20}$ Interview with Ms. Hj. Agustina Damayanti, S.E., M.T., Head Officer of SAMSAT Joint Office Sigi Regency, 16 July 2020.

${ }^{21}$ Interview with Mr. Abdul Rachman S.H., Head Officer of SAMSAT Joint Office Palu City, 15 July 2020.
} 
livelihoods ${ }^{22}$. During the emergency response period, they received assistance with necessities from the government. The stagnation of the economy has resulted in taxpayers prioritizing daily basic fulfillment rather than paying taxes. Based on the Central Sulawesi Governor Regulation Number 25 of 2018, a tax arrears reduction/relief mechanism is regulated which takes place during the collection period from May to November 2018. Article 2 of the Governor Regulation stipulates that the principle of tax arrears, write-offs, and reduction of administrative sanctions in the form of vehicle tax fines and exemption from Principal BBNKB II and so on is given in the context of:

1) Follow-up data tracing of vehicles that did not re-register until December 2017;

2) Intensification efforts through exploring the potential for tax on vehicles that do not re-register and the potential for BBNKB II and so on; and

3) Efforts to increase public awareness in paying vehicle tax and BBNKB through providing stimulus.

Article 3 of the Governor Regulation then stipulates that the provision of a reduction in the principal of tax arrears and the elimination of regional tax administration sanctions, $P K B$ given to all types of vehicles. The types of vehicles that receive a reduction in the principal of tax arrears and the elimination of regional tax administration sanctions, namely:

1) Two-wheeled vehicles which are private property and vehicles belong to the official;

2) Four-wheeled motorized vehicles which are private property, official property, and vehicles for public transportation;

3) Three-wheeled motorized vehicle.

Providing a reduction in the principal of tax arrears for vehicles that have not reregistered and paid off for five years from the time the tax became due, a tax

22 Pemerintah Provinsi Sulawesi Tengah. Laporan Finalisasi Data dan Informasi Bencana Gempa Bumi, Tsunami, dan Likuifaksi di Sulawesi Tengah per tanggal 28 Desember 2018. Retrieved from https://www.humanitarianresponse.info/sites/www.humanitarianresponse.info/files/documents/fil es/lap ke gub 20 des 2018.pdf. accessed 12 May 122020. 
reduction of $50 \%$ is given for the first two years. The elimination of administrative sanctions for vehicles that do not re-register and pay off until the 2017 validity period and under, as well as arrears of less than five years, will be given a $100 \%$ administrative sanction exemption. For vehicles with a validity period of 2018, if they are due and/or have not re-registered and paid the vehicle tax, they will still be subject to administrative sanctions in the form of late fees per statutory regulations.

In addition, it is stipulated that the BBNKB principal exemption upon second delivery onwards is given to vehicles originating from outside the region operating in the regional area and vehicles within the region operating in all regional areas. Reductions in arrears, write-offs, and exemptions can be granted if the vehicle owner can show administrative documents/data in the form of:

1) Taxpayer identity card;

2) Original documents/data on vehicle ownership, namely STNK and/or BPKB;

3) Fiscal certificate for vehicles outside the region;

4) Last year's Regional Tax Assessment;

5) Vehicle purchase receipt (proof of sale and purchase);

6) Other requirements are following statutory provisions.

Reductions in arrears, write-offs, and exemptions apply to all SAMSAT Joint Offices in the regions affected by natural disaster areas. So that taxpayers have a grace period to settle their tax obligations/tax debt.

\section{c. Due Process Damage to the infrastructure of the SAMSAT office (especially in Sigi Regency), which hinder services to taxpayers}

The SAMSAT Joint Office service building in Sigi Regency was damaged quite badly after the earthquake. So that for the time being, services to taxpayers are transferred to the building of SAMSAT Joint Office at Jl. Karanja Lembah (temporary office) to bring services closer to taxpayers during office reconstruction. To support the realization of tax revenues, the SAMSAT Joint Office has also activated the Mobile SAMSAT (SAMKel) system and "door to door" system by collecting taxes from house to house in areas far from the SAMSAT Joint Office. The use of the information system 
in the SAMOLNAS (National Online SAMSAT) application can also assist taxpayers in fulfilling their obligations. However, vehicle tax payments through this application are only for the current year that does not have vehicle tax arrears or vehicle tax arrears under one year ${ }^{23}$.

Furthermore, the SAMSAT Region X Joint Office in Donggala Regency and the SAMSAT Region XI Joint Office in Sigi Regency has not had the status of a full SAMSAT Joint Office until now. This hampers the mobilization of taxpayers who want to pay their taxes because for certain matters they still have to visit the SAMSAT Joint Office in Palu City, which has the status of the full SAMSAT Joint Office. An increase in the status of the Joint Office of SAMSAT Donggala is highly expected, given the unique geographical conditions of Donggala Regency and a challenge in itself in efforts to intensify vehicle tax revenues.

In Tax Law, there is the Purchasing Power Principal Theory which states that the basis of justice lies in the consequences of tax collection. That is, collecting taxes means drawing purchasing power from community households for state households. Farther, the state will channel it back to society in the form of maintaining public welfare. Thus, the interests of the entire community take precedence ${ }^{24}$. This is in line with the Buying Style Theory in tax collection, which in essence emphasizes that tax payments made to the state are intended to maintain the people in the country concerned. In other words, the benefit of society will be guaranteed by paying taxes 25 .

For a given natural disaster, the revenue impact depends on the extent of economic diversification and the composition of tax revenue, as effects differ across economic sectors and revenue sources (income taxes, consumption taxes, custom duties, and so on $)^{26}$. According to some estimates, natural disasters have raised government expenditure by an average of 15 percent and lowered revenue by about 10 percent

\footnotetext{
${ }^{23}$ Interview with Mr. Abdul Rachman S.H., Head Officer of SAMSAT Joint Office Palu City, 15 July 2020.

${ }^{24}$ Mardiasmo. (2011). Perpajakan, Edisi Revisi. Yogyakarta: Penerbit ANDI. p. 4.

${ }^{25}$ Wirawan Ilyas B. and Richard Burton. (2007). "Hukum Pajak Edisi 3". Jakarta: Penerbit Salemba Empat. p. 17.

${ }^{26}$ Fiscal Affairs Department, International Monetary Fund. (2017). Fiscal Policy, How to Manage the Fiscal Costs of Natural Disaster". Washington: Fiscal Affairs Department, International Monetary Fund, p. 4.
} 
over the five years following a disaster, leading to a substantial increase in the overall budget deficit.

\subsection{Vehicle Tax Collection Process After Disaster in New South Wales, Australia}

The state of New South Wales is Australia's largest state economy. Sydney is the capital of the state and it is located on the eastern coast of NSW. This state has the highest population of any state in Australia, with 8,172,500 residents as of 31 December 202027. Similar to people in Indonesia, the people of NSW also experience natural disasters quite often, the current happened when the Australian government declared a natural disaster in large swaths of NSW as heavy rains batter the state and force thousands to evacuate. Rains have been inundating communities since Thursday, but parts of the east coast tipped into crisis on Saturday as a major dam overflowed, adding to swollen rivers and causing flash flooding. The NSW and the federal government have signed 16 natural disaster declarations in areas spanning the central and mid-north coast in this particular case ${ }^{28}$.

Figure 3. The map of NSW, Australia

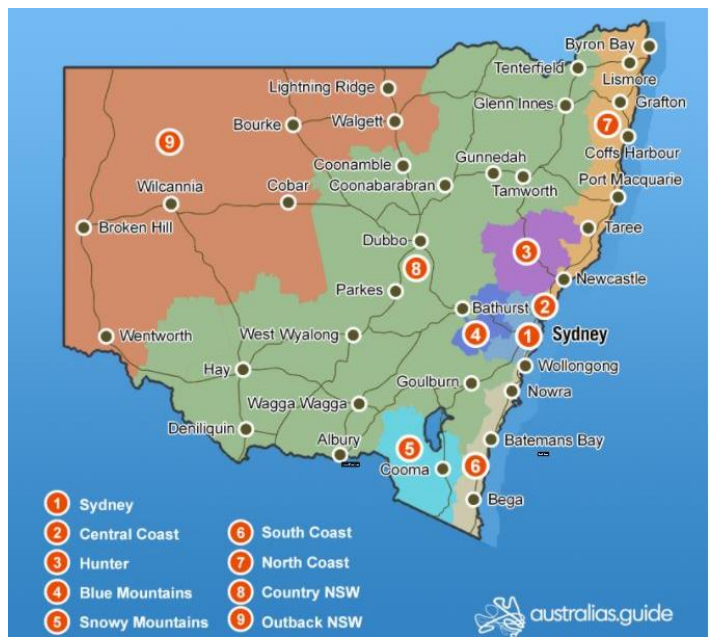

Source: Australia Guide, New South Wales, $2021^{29}$

27 The Government of Australia. Key Facts About NSW. Retrieved from https://www.nsw.gov.au/aboutnsw/key-facts-about-nsw, (accessed on 13 September 2021)

${ }^{28}$ CNN. Parts of Australia Declare Natural Disaster During 'Once in 100 Years' Floods. Retrieved from https://edition.cnn.com/2021/03/21/australia/australia-flood-natural-disaster-intl-hnk/index.html, (accessed on 13 September 2021)

${ }_{29}$ Australia Guide. New South Wales. Retrieved from https://www.australias.guide/nsw/maps/, (accessed on 13 September 2021) 
The regulation on vehicle tax collection for victims of natural disasters in the state of New South Wales (hereinafter abbreviated as NSW) territory, applies with Disaster Declaration, which is a list containing areas affected by natural disasters that is continuously updated by the government. With this document, individuals and communities affected by natural disasters can access various special assistance. This document is issued by the NSW government and is part of the Australian Government reference number ${ }^{30}$. Concerning vehicle tax, if a vehicle was written off in a declared natural disaster, then the NSW government may be able to refund any vehicle duty the owner paid on a replacement vehicle. The government may also be able to ${ }^{31}$ :

1) Give people more time to lodge any documents or returns;

2) Defer enforcing any fines against the people;

3) Extend payment deadlines;

4) Agree not to charge the interest;

5) Arrange for people to pay any debts to the government in installments.

The official website of the NSW government also provides information regarding the procedure for claiming vehicles lost or damaged in a natural disaster. There is a downloadable form to fill by a citizen on the website to apply for a vehicle duty refund. After a citizen filling the form and send it to the official, a customer service staff member will check that the residential area of the citizen or the area that the citizen had visiting experience a genuine natural disaster or include in an emergency declared area. A citizen may be eligible for a vehicle duty refund if 32 :

1) They had comprehensive insurance for your written-off vehicle.

2) Their insurance does not cover the duty for a replacement vehicle.

3) They paid the duty on your replacement vehicle in NSW.

30 New South Wales Government. Natural Disaster Declaration. Retrieved from https://www.nsw.gov.au/disaster-recovery/natural-disaster-declarations, (accessed on 13 September 2021)

31 New South Wales Government. Natural Disaster Duty Relief. Retrieved from https://www.revenue.nsw.gov.au/taxes-duties-levies-royalties/motor-vehicle-duty/relief, (accessed on 13 September 2021)

32 Ibid. 
The amount that the citizen receive will be the duty payable on the lower cost of the replacement vehicle or the value of the insurance payout for the written-off vehicle ${ }^{33}$. The citizen will also need to meet specific requirements to receive some free services or products (for example, proof of identity requirements for a free replacement license). In line with this, the following products can be replaced for free if a citizen has been affected by a natural disaster or emergency ${ }^{34}$ :

1) Driver license (including learner, $P 1, P 2$, and unrestricted) ${ }^{35}$;

2) Mobility Parking Scheme (MPS) permit;

3) NSW Photo Card;

4) Boat license;

5) Personal Watercraft (PWC) license;

6) Certificate of Registration for a vehicle and/or vessel (and registration label if applicable);

7) Number plates (number plate reissue, remake, or hold fees may also be waived);

8) e-toll tag;

9) Learner driver logbook.

The government of NSW also putting up options to waived or refunded fees if a citizen is affected by a natural disaster or emergency. All vehicles except trailers and caravans must have Compulsory Third Party (CTP) insurance ${ }^{36}$. All normal CTP fees apply. Fees that can be waived or refunded are listed below:

1) Transfer of registration fee.

After a disaster happens, if a citizen buys a vehicle to replace one damaged they don't need to pay for the transfer registration fee when moving the

\footnotetext{
33 Ibid.

${ }^{34}$ NSW Government. Fee Refunds or Waivers After a Natural Disaster. Retrieved from https://www.nsw.gov.au/topics/vehicle-registration/fees-concessions-forms/natural-disasters, (accessed on 13 September 2021)

35 Similar to driver license (SIM) A, B, C, and D in Indonesia.

36 This insurance provides compensation for people injured or killed when a vehicle is involved in an accident. CTP insurance is compulsory in all states of Australia. A citizen cannot register their vehicle without having a policy in place. See: Greenslips. Compulsory Third Party (CTP) Insurance. Retrieved from https://www.greenslips.com.au/ctp-insurance.html, (accessed on 13 September 2021)
} 
registration to the replacement vehicle.

2) Late registration transfer surcharge.

If a disaster resulted in deferment in transferring the registration of a vehicle, then the late surcharge may be waived.

3) Registration cancellation fee.

A citizen may be qualified for a registration cancellation fee waived for the written-off vehicle if it is written-off due to a natural disaster. This also applies to a case when a vehicle is damaged due to a natural disaster then the citizen may be qualified for registration cancellation fee waived.

4) Late vessel registration renewal fee.

If a citizen delayed in renewing vehicle registration for reasons relating to the declared natural disaster, the fee may be waived.

5) Inspection fees for written-off vehicles.

Once a vehicle has been notified to the Written-off Vehicle Register (WOVR) ${ }^{37}$, the government automatically cancels the vehicle's registration after 14 days. Registration for written-off vehicles can only be re-established if the registered vehicle operator has been issued with an Authorization to Repair notice. The vehicle must be repaired and inspected to confirm that it meets the government requirements. The Vehicle Identification Inspection Unit (VIIU) inspection fee may be waived for written-off vehicles that meet certain criteria. If a citizen already has an Unregistered Vehicle Inspection Report (also known as a blue slip) for the written-off vehicle, the cost may be refunded.

6) Number plate reissue, remake and hold fees.

If a vehicle's number plates (general issue and special number plates) are lost

\footnotetext{
37 Written-Off Vehicle Register (WOVR) is the register records the written-off vehicle's identifiers and specific information about the damage to the vehicle. This Australia national system was developed to reduce the problem of re-birthing stolen vehicles. The register records the written-off vehicle's identifiers and specific information about the damage to the vehicle. The WOVR records whether the vehicle is a Statutory write-off (meaning the vehicle cannot be re-licensed) or Repairable write-off (meaning the vehicle may be repaired, inspected and then re-licensed). Once a vehicle has been notified as a write-off, the license will be cancelled and the number plates must be returned within 28 days. See: The Government of Western Australia, Department of Transport, Write-Off A Vehicle. Retrieved from https://www.transport.wa.gov.au/licensing/write-off-a-vehicle.asp, (accessed on 13 September 2021)
} 
or destroyed in a natural disaster, the re-issue, remake, or hold fees may be waived. The whole process started when the owner provides a completed Number Plates and/or Cancellation of the Registration ${ }^{38}$ Form to the service center to reapply for the number plates.

7) Vehicle stamp duty refunds.

The government of NSW does not refund or waive stamp duty on vehicles ${ }^{39}$ written off due to a natural disaster. However, if a citizen buys a replacement vehicle due to a natural disaster, they can apply for a refund to Revenue NSW.

When a natural disaster happened, usually it is followed by damaged/lost items and documents. Therefore, the NSW government provides the service to replace a license, permit, or photo card that had been damaged/lost after a disaster. To assist the citizen so they can have the free replacement products as quickly and easily as possible following a natural disaster, the normal license replacement procedures and proof of identity requirements are simplified. For example, the simplified proof of identity requirements to get a free replacement licensing product, if the citizen's photo is stored in the system, they can use either a list 1 proof of identity document or a list $2^{40}$ proof of identity document. Their signature stored in the system must match the signature on the proof of identity document they provide, or on the application form. If the proof of identity is lost or destroyed during a natural disaster and the government does not have a stored photograph of the citizen, they can answer some identity questions at a service center to receive a free interim driver's license receipt.

Furthermore, simplified license replacement also can be accessed using the Australia Post service where the citizen can request a replacement license using a Photo Kit

\footnotetext{
38 The form is available in https://www.nsw.gov.au/topics/vehicle-registration/fees-concessionsforms/natural-disasters website.

${ }^{39}$ Stamp duty is a tax levied by state governments for official documents. It is generally payable on the purchase of motor vehicles and other things such as land or shares. It is a one-off tax paid when transferring ownership, like when buying a new or used car from a dealer or privately. See: Carsguide. Stamp Duty on Cars: What is Stamp Duty \& How Much is it on a Vehicle in Australia? Retrieved from https://www.carsguide.com.au/car-advice/stamp-duty-for-cars-explained-31021, (accessed on 13 September 2021). This is similar to vehicle tax (Pajak Kendaraan Bermotor or PKB) in Indonesia.

40 The detail of these lists can be access in $\underline{\text { https://roads- }}$ waterways.transport.nsw.gov.au/roads/licence/proof-of-identity/proving-your-identity/index.html.
} 
form ${ }^{41}$. If the citizen cannot get to a service center, and an Australia Post service is available, they may be able to request it through the postal service. Otherwise, if the citizen cannot get to a service center and an Australia Post service is not available near them, they may request a free interim driver license receipt over the phone. In some situations, they may be able to renew their license over the phone ${ }^{42}$.

The explanation above shows that the NSW government has implemented an integrated online system to deal with vehicle tax after an emersion of a disaster. While the citizen is already familiar with the internet and online system. This is different with people in Indonesia, especially those who live in remote areas or areas with unstable internet networks, the internet service provider does not even exist in some areas yet. When a natural disaster occurred in Central Sulawesi on 28 September 2018, more than 500 cellular telecommunications Base Transceiver stations or BTS could not function, partly because of the cessation of electricity supply from the State Electricity Company or $P L N^{43}$. Subsequently, the people only used the manual system where they can have a face-to-face meeting with the government official to deal with their complaints or requests. Hence, Indonesia requires an integrated tax system especially for the tax collection after disaster because the state needs funds to rebuild infrastructure while it will be morally wrong for the government to collect taxes on taxpayers when they are in an unhappy condition as disaster victims. This is in line with the principle of tax collection by Adam Smith and the utilitarianism notion by Jeremy Bentham.

Moreover, the system of tax vehicle collection after a disaster that applies in NSW and Indonesia also has something in common: there is a category for citizens who can receive a vehicle tax reduction facility or even a write-off of vehicle tax debt. Because

\footnotetext{
41 This form also available online in $\underline{\text { https://roads- }}$ waterways.transport.nsw.gov.au/documents/about/forms/45070563-photo-kit-nsw-licensee-tempoverseas.pdf.

42 The government provide a phone number in 132213 for more information. See: NSW Government. Fee Refunds or Waivers After a Natural Disaster. Retrieved from https://www.nsw.gov.au/topics/vehicle-registration/fees-concessions-forms/naturaldisasters\#which-products-we-can-waive, (accessed on 13 September 2021)

${ }^{43}$ Kementerian Komunikasi dan Informasi Republik Indonesia. Jaringan Telekomunikasi Seluler di Palu dan Donggala Belum Berfungsi Optimal. Retrieved from https://kominfo.go.id/content/detail/14791/jaringan-telekomunikasi-seluler-di-palu-dan-donggalabelum-berfungsi-optimal/0/sorotan media, (accessed on 13 September 2021)
} 
victims of natural disasters should be supported by the state so that they can immediately organize their lives socially and economically so that they can return to normal activities and contribute to development after natural disasters. To achieve this, the government should create an integrated and effective tax collection for reporting and collecting the vehicle tax to support the achievement of post-natural disaster economic growth.

\section{Conclusion}

The provision of tax collection after a disaster in Indonesia is made by the local governments because this part has not been regulated in law made by the central government. The main factor inhibiting post-disaster tax payments is the condition of the community who is in inconvenience to pay the tax bill, in addition to several factors that arise from the post-disaster situation itself. For example, loss/damage of vehicle ownership documents or even loss of vehicles that are tax objects. According to the principle of convenient payment by Adam Smith and utilitarianism by Jeremy Bentham, tax collection should be done when citizens feel safe and comfortable with their lives. Compare to the system that had been used in NSW, Australia, Indonesia must build a system that can accommodate the needs of people regarding vehicle tax collection after a disaster. In principle, taxes should be collected in conditions that are convenient for taxpayers, so the government must adopt humane tax collection methods and comply with statutory provisions.

\section{References}

\section{Books}

Adrian Sutedi. (2008). Hukum Pajak dan Retribusi Daerah. Bogor: Ghalia Indonesia.

Angger Sigit Pramukti and Fuady Primaharsya. (2015). Pokok-pokok Hukum Perpajakan. Yogyakarta: Pustaka Yustisia.

Aristanti Widyaningsih. (2011). Hukum Pajak dan Perpajakan dengan Pendekatan Mind Map. Bandung: Alfabeta.

Fiscal Affairs Department, International Monetary Fund. (2017). Fiscal Policy, How to Manage The Fiscal Costs of Natural Disaster. Washington: Fiscal Affairs Department, International Monetary Fund.

H. Bohari. (2004). Pengantar Hukum Pajak. Jakarta: PT. Rajagrafindo Persada. 
Joseph Losco and Leonard Williams. (2015). Political Theory: Kajian Klasik dan Kontemporer Edisi Kedua. (Indonesian Translation by Haris Munandar). Jakarta: PT. Rajagrafindo Persada.

Soerjono Soekanto. (2012). Pengantar Penelitian Hukum. Jakarta: UI Press.

Soerjono kanto and Sri Mamudji. (2006) Penelitian Hukum Normatif. Jakarta: PT. Raja Grafindo Persada.

Mardiasmo. Perpajakan, Edisi Revisi. (2011). Yogyakarta: Penerbit ANDI.

Mukti Fajar and Yulianto Achmad. (2010). Dualisme Penelitian Hukum Empiris dan Normatif, Yogyakarta: Pustaka Pelajar.

M. Djafar Saidi. (2008). Perlindungan Hukum Wajib Pajak dalam Penyelesaian Sengketa Pajak. Jakarta: Rajawali Pers.

Wirawan B. Ilyas and Richard Burton. (2007). Hukum Pajak Edisi 3. Jakarta: Penerbit Salemba Empat.

\section{Journal Article}

Hafifah Nasution and Agista Aliffioni. (2018). Analisis Efektivitas Penagihan Pajak dengan Surat Paksa dan Penyitaan untuk Meningkatkan Penerimaan Pajak pada Kantor Pelayanan Pajak Pratama Bekasi Utara. Jurnal Wahana Akuntansi Vol. 13 (2) 2018.

Hidayat, Rudi and Charoline Cheisviyanny. (2013). Pengaruh Kualitas Penetapan Pajak dan Tindakan Penagihan Aktif Terhadap Pencairan Tunggakan Pajak. Jurnal Wahana Riset Akuntansi, Vol. 1 No. 1 April 2013.

\section{Legislations}

The 1945 Constitution of the Republic of Indonesia.

Law No. 2008 Year 2009 Concerning Local Taxes and Levies (State Gazette Year 2009 No. 130; Addition to State Gazette No. 5049).

Central Sulawesi Governor, Peraturan Gubernur Sulawesi Tengah Nomor 25 Tahun 2018 tentang Pengurangan Pokok Tunggakan Pajak, Penghapusan, dan Pembebasan Sanksi Administrasi Berupa Denda Pajak Kendaraan Bermotor dan Pembebasan Pokok Bea Balik Nama Kendaraan Bermotor Kedua dan Seterusnya di Provinsi Sulawesi Tengah.

\section{Official Web}

Badan Pusat Statistik Republik Indonesia. Perkembangan Jumlah Kendaraan Bermotor Menurut Jenis,

1949-2018.

Retrieved

from 
https://www.bps.go.id/linkTableDinamis/view/id/1133, (accessed on 13 March 2019)

Carsguide. Stamp Duty on Cars: What is Stamp Duty \& How Much is it on a Vehicle in Australia? Retrieved from https://www.carsguide.com.au/car-advice/stampduty-for-cars-explained-31021, (accessed on 13 September 2021)

CNN. Parts of Australia Declare Natural Disaster During 'Once in 100 Years' Floods. Retrieved from https://edition.cnn.com/2021/03/21/australia/australiaflood-natural-disaster-intl-hnk/index.html, (accessed on 13 September 2021.

Greenslips. Compulsory Third Party (CTP) Insurance. Retrieved from https://www.greenslips.com.au/ctp-insurance.html, (accessed on 13 September 2021)

IISAUC. Utilitarianisme Jeremy Bentham. Retrieved from https://www.iisauc.org/2020/07/12/utilitarianisme-jeremy-bentham/, (accessed on September 13 2021)

Irsyaad Wijaya. Polri: Korban Gempa dan Tsunami Dipermudah Urus Surat Kendaraan Hilang. Retrieved from https://otomania.gridoto.com/read/241190510/polrikorban-gempa-dan-tsunami-dipermudah-urus-surat-kendaraan-hilang, (accessed on 28 November 2020)

Kementerian Komunikasi dan Informasi Republik Indonesia. Jaringan Telekomunikasi Seluler di Palu dan Donggala Belum Berfungsi Optimal. Retrieved from https://kominfo.go.id/content/detail/14791/jaringan-telekomunikasiseluler-di-palu-dan-donggala-belum-berfungsi-optimal/0/sorotan media, (accessed on 13 September 2021)

Kompas. Bangkai Kendaraan Bermotor Akibat Bencana Gempa di Kota Palu. Retrieved from

https://foto.kompas.com/photo/read/2018/09/30/15383242987b6/Bangka i-Kendaraan-Bermotor-Akibat-Bencana-Gempa-di-Kota-Palu, (accessed on 30 November 2020)

Ministry of Finance Republic of Indonesia, Anggaran Pendapatan dan Belanja Negara Tahun 2020. Retrieved from https://www.kemenkeu.go.id/single-page/apbn2020/ (accessed on 11 March 2020)

National Geographic. The Ring of Fire. Retrieved from https://www.nationalgeographic.com/science/earth/ring-of-fire/, (accessed on 28 November 2020)

NSW Government. Natural Disaster Declaration. Retrieved from https://www.nsw.gov.au/disaster-recovery/natural-disaster-declarations, (accessed on 13 September 2021)

Natural Disaster Duty Relief. Retrieved from https://www.revenue.nsw.gov.au/taxes-duties-levies-royalties/motor-vehicleduty/relief, (accessed on 13 September 2021) 
Fee Refunds or Waivers After a Natural Disaster. Retrieved from https://www.nsw.gov.au/topics/vehicle-registration/fees-concessionsforms/natural-disasters, (accessed on 13 September 2021)

Fee Refunds or Waivers After a Natural Disaster. Retrieved from https://www.nsw.gov.au/topics/vehicle-registration/fees-concessions-

forms/natural-disasters\#which-products-we-can-waive, (accessed on 13 September 2021)

Pemerintah Daerah Provinsi Sulawesi Tengah. Laporan Finalisasi Data dan Informasi Bencana Gempa Bumi, Tsunami, dan Likuifaksi di Sulawesi Tengah per tanggal 28 Desember $2018 . \quad$ Retrieved from https://www.humanitarianresponse.info/sites/www.humanitarianresponse.i nfo/files/documents/files/lap ke gub 20 des 2018.pdf, (accessed 12 May 2020)

Rizka Novianti Pertiwi, Devi Farah Azizah, and Bondan Catur Kurniawan. Analisis Efektifitas Pemungutan Pajak Bumi dan Bangunan. Retrieved from https://media.neliti.com/media/publications/193071-ID-analisis-efektivitaspemungutan-pajak-bu.pdf, accessed on 30 November 2020.

Rony Sandhi. Melihat Antusias Warga Bayar Pajak Kendaraan Bermotor Pasca Bencana. Retrieved from https://radarsulteng.id/14850-2/ (accessed on 30 November 2020)

The Government of Australia. Key Facts About NSW. Retrieved from https://www.nsw.gov.au/about-nsw/key-facts-about-nsw, (accessed on 13 September 2021)

The Government of Western Australia, Department of Transport, Write-Off A Vehicle. Retrieved from https://www.transport.wa.gov.au/licensing/write-off-avehicle.asp, (accessed on 13 September 2021) 